\title{
BPHL wt Allele
}

National Cancer Institute

\section{Source}

National Cancer Institute. BPHL wt Allele. NCI Thesaurus. Code C50380.

Human BPHL wild-type allele is located within $6 p 25$ and is approximately $34 \mathrm{~kb}$ in length.

This allele, which encodes valacyclovir hydrolase protein, is involved in the activation of valine ester prodrugs and other amino acid ester prodrugs of nucleoside analogs. 